\title{
Chapter 1. Comparative Perspectives on Austronesian Houses: An Introductory Essay
}

\author{
James J. Fox
}

The eight papers that comprise this volume share a common objective. Their purpose is to examine the spatial organization of a variety of Austronesian houses and to relate the domestic design of these houses to the social and ritual practices of the specific groups who reside within them.

Throughout the Austronesian-speaking world, houses are given great prominence. Many houses are stunning architectural creations. Their construction is a subject of notable study. Such houses - as well as those that are far less striking - are invariably more than they appear to be, and certainly more than simple physical residences. Although a house has a physical referent, the category of 'house' may be used abstractly to distinguish, not just households, but social groups of varying sizes. The 'house' in this sense is a cultural category of fundamental importance. It defines a social group, which is not necessarily the same as the house's residential group.

The house, as a physical entity and as a cultural category, has the capacity to provide social continuity. The memory of a succession of houses, or of a succession within one house, can be an index of important events in the past. Equally important is the role of the house as a repository of ancestral objects that provide physical evidence of a specific continuity with the past. It is these objects stored within the house that are a particular focus in asserting continuity with the past.

Most Austronesian houses also possess what may be called their particular 'ritual attractor'. This ritual attractor is part of the structure of the house. It may be a specific post, beam, platform, niche, altar or enclosure that has a pre-eminence among the other parts of the house and, as such, represents, in a concentrated form, the house as a whole. The rituals of the houses acknowledge this attractor, generally from the moment of construction.

The house itself, and not just the objects and elements within it, can also constitute a ritually ordered structure. As such, this order can be conceived of as a representation of a cosmological order. In some Austronesian societies, the house is regarded as the ancestral 'embodiment' of the group it represents. As either representation or embodiment, the house may become a centre - a 
combination of theatre and temple - for the performance of the ceremonies of social life.

Thus, in a complex way, the house is culturally emblematic: it has a clear, concrete representation but relates to and embodies abstract social ideals and a variety of culturally specific values. From a physical structure - a particular arrangement of posts and beams - one can begin to trace the ideals and social values of a society. To do this is to view a society from 'inside' its houses. All of the essays in this volume adopt this perspective, hence the title of this volume: Inside Austronesian houses.

The houses considered in this volume range from longhouses in Borneo to Maori meeting-houses in New Zealand and from the magnificent houses of the Minangkabau of Sumatra to the simple, somewhat ramshackle dwellings of the population of Goodenough Island. An examination of the diversity of these houses gives some indication of the variety of Austronesian houses through island South-East Asia to Melanesia and the Pacific. The intention is to relate these various examples of domestic design to social activities and ritual practice and thereby to consider both commonalities and differences in the use of domestic space in different regions of the Austronesian-speaking world.

Of the three papers on Borneo houses, Jennifer Alexander's considers the Lahanan longhouse, a massive structure of hardwoods that can be virtually coterminous with an entire village settlement. The Lahanan are a core group of the Kajang in the Belaga region of Sarawak's Seventh Division. Alexander examines the layout of these Lahanan houses and their division into separate apartments along an extended common gallery.

Each longhouse is associated with its headman and the Lahanan aristocrats who constitute a 'house-owning group' and trace their origin to a founding ancestor. Alexander's paper examines the composition of apartments, and their differentiation, continuity and role in the organization of labour. The Lahanan case makes an excellent contrast with both the Gerai longhouses studied by Christine Helliwell and the Iban longhouses studied by Clifford Sather.

The Gerai are a Dayak community in Kabupaten Ketapang in Kalimantan Barat. Several longhouses make up one village. Increasingly, however, these longhouses are giving way to free-standing dwellings of individual families. The Gerai house, like the Lahanan house, is divided into an 'inner division' consisting of individual apartments and an outer public gallery. Gerai longhouses, however, are not 'owned' by a particular aristocratic house-owning group. 'Each individual household owns the nails, planks, strips of bamboo, lengths of rattan, units of thatch and so on which together comprise its longhouse apartment.' Helliwell argues that to consider such a longhouse as a collection of individual apartments neglects 'the relationships that flow from one apartment to another, tying them together into a community'. She points to a permeability of partitions 
and the flow of sound and light that foster an 'uninterrupted sociability from one end of the longhouse to the other'.

Clifford Sather provides a detailed examination of the Iban longhouse, drawing on specific ethnographic material from the Saribas Iban along the Paku River in lower Second Division of Sarawak. Like the Lahanan and Gerai houses, the Iban longhouse consists of a series of apartments that front onto an unpartitioned gallery available for communal use. Every Iban house is identified with a territorial domain in which individual families grow crops and observe the customary rules and ritual interdictions of the community. Each house has its headman and elders but neither of these constitutes an aristocracy as they do among the Lahanan. Complementing these elders is a custodial figure associated with the origin of the house whose ritual role is to preserve the well-being of the longhouse community. The longhouse itself provides a physical representation of its origin structure in the arrangement of its houseposts. Within the defined structure, Sather examines the performance of Iban rituals and the "multiple "orders" of meaning' that they generate.

Cecilia Ng's paper is concerned with principles of domestic spatial organization among the Minangkabau of Sumatra. Based on fieldwork in Nagari Koto nan Gadang in the district of Lima Puluh Kota in West Sumatra, this paper focuses on use of space within the house and on the role of women as organizers and participants in the performance of ceremonies whose enactment is carefully set out within the house. Houses, in this case, are associated with core groups of women who provide the 'source of continuity' in society, whereas men circulate as 'agents of continuity'. Men's lives are defined by a series of outward movements while women's lives are marked by movement within the house. Generations of women move through the house reproducing lineage continuity. Thus, in Ng's words, the allocation of space inside the house is 'a template of the key definitions of male and female identity'.

The Rotinese house presents yet another form of the Austronesian house. Although certain houses, by their history, ancestral associations or by common agreement become the ceremonial focus of much larger social groups, most houses in eastern Indonesia tend to be single or extended family residences. Houses may thus be distinguished by their ancestry as well as by the group with which they are identified, and are categorized accordingly. Among the Rotinese, who number over 100000 and who now live on both the island of Roti and on the neighbouring island of Timor, there exists a strong ethic to distinguish among the traditions of the eighteen historically recognized, former domains of the island. The traditions of the house follow the traditions of the domains.

The paper on the Rotinese house is concerned primarily with the traditions of the house in the domain of Termanu, a domain of the central north coast of the island. It focuses on the narrative origin of the house and on the house's 
physical layout as an oriented structure and as a 'memory palace' - a mnemonic cultural design for the remembrance of the past. Like longhouses in Borneo or the houses of the Minangkabau, Rotinese houses are a locus for the performance of rituals but these houses do not provide the same scope for ceremonial enactment. Sections within the house are markers of significance rather than fully-fledged performance sites. Much of the house consists of an inner sanctum that is closed to outsiders. Large ceremonial gatherings spill out to surround the house where rituals are performed, leaving always a portion of the house as a place of 'inner mystery'.

Similar features can be seen in the houses in Melanesia and in the Pacific. Writing of Goodenough Island in the D'Entrecasteaux Group at the eastern end of Papua New Guinea, Michael Young describes the Kalauna house as a 'house of secrets'. Architecturally simple structures, Kalauna houses are the repositories of their owners' magical paraphernalia that constitute the secret heirlooms of the house. Kept well away from visitors, these heirlooms include locked boxes of shell valuables, baskets of bone relics and yam stones and, most importantly, fist-sized black stones that are considered to be inhabited by ancestral spirits.

As is the case with houses in many parts of eastern Indonesia, the Kalauna house has to be considered within a wider spatial setting and in relation to points of orientation within this space. Thus Kalauna hamlets are marked out by various stone 'sitting platforms' (atuaha) that are built and identified with groups of lineally related men (unuma). The houses of particular groups in a hamlet are aligned to face their associated lithic monument. Whereas in South-East Asia the dead are often layed out in a specific area within the house, the dead in a Kalauna hamlet are made 'to sit up' on their atuaha in front of house (Young 1971:22-23). The rituals of the house must be taken to include the rituals of the atuaha with which it forms an integral part.

Toon van Meijl's paper on the Maori of New Zealand highlights a similar relationship between the meeting-house and the ceremonial courtyard (marae) for which the meeting-house forms the focal point. Meeting-houses and marae are seen as 'going together' and are commonly invoked by visiting orators in parallel phrases:

House standing here, I greet you;

Marae lying here, I greet you.

More cryptically expressed in ritual language, marae and meeting-house are associated with the Maori gods of war (Tuu-matauenga) and peace (Rongo-ma-tane) who are represented as outside and inside:

Tuu outside, Rongo inside. 
Meeting-houses are generally named after an ancestor and usually linked to a haapu or 'subtribe' group. Van Meijl's paper examines contemporary meeting-houses, their symbolism and the notion of timelessness evoked through the ceremonies within these houses. The spatial coordinates of the house are linked to coordinates of time and both are condensed in the performance of ceremonies. Van Meijl contrasts this sense of time with the evidence of the historical changes that houses have undergone since the arrival of the Europeans and speculates on how these changes may continue.

The concluding paper in this collection is provided by Roxana Waterson who has written a major comparative study of the house entitled The living house: an anthropology of architecture in South-East Asia (1990). She is also a noted authority on the tongkonan or family houses of origin among the Toraja of Sulawesi among whom she has done considerable ethnographic research. In her paper, Waterson considers many of the 'shared themes in the uses of space' touched on by other papers in the volume. These include the idea of the house as an animate entity, as a kinship unit, as a forum for the expression of social relationships and as an image of power and growth. The paper offers a broad perspective on the traditions among the Austronesians and an appropriate conclusion to the volume.

\section{The Comparative Austronesian Focus}

Versions of these papers were initially presented at a Workshop on House and Household held in the Research School of Pacific Studies of The Australian National University as part of its Comparative Austronesian Project. This Comparative Austronesian Project was established, as an interdisciplinary project, to focus research on the Austronesian-speaking populations as a whole. Its goals were (1) to develop a historically-based understanding of the Austronesian-speaking populations, (2) to fashion a general framework and common vocabulary with which to define the distinguishing features of an Austronesian heritage and (3) to make comparisons not just between closely related regional groups but between cultures and societies from the entire Austronesian world.

The Austronesian language family is possibly the largest language family in the world. Native speakers of distinct Austronesian languages can be found from the island of Mayotte off the western coast of Madagascar to Easter Island in the Pacific, a distance of some 15000 kilometres. From Taiwan through the Philippines and Indonesia, westward to Madagascar, and eastward along the coast of New Guinea through the islands of Melanesia to Micronesia and the whole of the Pacific, the Austronesian languages extend over an enormous geographical area. Pockets of these languages are also found in southern Vietnam and Cambodia, on the island of Hainan, and in the Mergui archipelago off the coast of Burma. It is estimated that there are around 1200 Austronesian languages 
currently spoken by approximately 270 million people (see Tryon 1993). The time-depth for the spread of the languages of the Austronesian family from a likely homeland on the south coast of China and/or Formosa is of the order of 6000-7000 years. The migrations of the Austronesian speakers, their changing modes of subsistence, their means of voyaging, their trade and their relations among themselves and with populations speaking other languages are all the subject of considerable research.

For anthropology as well as for linguistics, the Austronesians constitute a major field of study. How one approaches this study is a matter of critical importance. For the Comparative Austronesian Project, a linguistically attuned, historical perspective was deemed essential to an anthropological understanding of these cultures and to a comparative examination of them (see Bellwood, Fox and Tryon n.d.). Given the large number of Austronesian cultures, however, the papers in this volume represent a rather limited sample. A collection of papers of this kind can hardly be considered to constitute a systematic investigation. The purpose of this volume is quite different. Its intention is to identify a variety of resemblances and, at least implicitly, to point to several significant differences within the Austronesian field of study.

Each paper presents a detailed discussion of the cultural design and social usages of domestic space in a particular culture. These discussions taken together point to aspects of domestic cultural design that appear to be similar among different, in some cases widely separated, Austronesian populations. They also touch on a range of differences that may be of considerable importance to understanding the historical transformations that have occurred among the Austronesian populations. Thus even with this small collection of papers it is possible to pose a number of comparative questions, which in turn may open new directions for further analysis.

\section{The House as a Topic of Study}

A major impetus for the current study of the house as a focus of social organization and ritual activity has been the work of Claude Lévi-Strauss. In a series of lectures at the Collège de France from 1976 through 1981, Lévi-Strauss examined the concept of the 'house' in a survey of the social organization of societies ranging from the Canadian north-west coast through Indonesia, Melanesia, Polynesia, New Zealand, Madagascar and Micronesia. The summaries of these lectures were published in French in 1984 and in English in 1987.

Lévi-Strauss' intention, in his lectures, was to introduce the concept of 'house' as another 'type of social structure' - an intermediate structure between the elementary and complex structures which he had previously distinguished (Lévi-Strauss 1949, English translation 1969). Lévi-Strauss' inspiration for his analysis was derived from his understanding of the noble 'houses' of medieval 
Europe. The characteristics of such 'houses' were critically defined by: possession of a 'domain' consisting of material and immaterial wealth or honours; the extensive use of fictive kinship in alliance and adoption; and the transmission of the 'domain' - titles, prerogatives, and wealth — via women as well as men. These characteristics serve to undermine a simple reliance on principles of descent and exogamy for the perpetuation of social groups. As Lévi-Strauss (1987) remarks, one purpose in introducing the concept of 'house' was to address the weakness afflicting theoretical debates that are 'haunted by the idea of descent' (p.165). The 'house' can be seen as a forum in which a tension between conflicting principles of descent and alliance, property and residence, exogamy and endogamy are expressed and seemingly resolved. This resolution is, for Lévi-Strauss, unstable and illusory and is thus, borrowing Marxist terminology, a kind of 'fetishism'. From this perspective, therefore, the 'house' may serve as both an institution and an illusion.

In his lecture summaries, Lévi-Strauss makes two kinds of comments. The first relate his views (in a condensed, somewhat cryptic format) on 'house societies' as a type of structure. These comments are of particular relevance in terms of his earlier dichotomy between elementary and complex forms of social structures. His other comments consist of a variety of observations on societies selected mainly from among Austronesian-speaking populations in Indonesia, Melanesia, Madagascar and the Pacific. Rather than combine these observations as a set of specific Austronesian comparisons, Lévi-Strauss takes the opportunity to compare various examples of these Austronesian 'house societies' with others in North America and elsewhere. Many of his general remarks nonetheless pertain directly to comparisons among Austronesian societies.

In his examination of 'house societies', Lévi-Strauss was in effect reverting to an older tradition in anthropology that began with Lewis Henry Morgan in his classic study of Houses and house-life of the American aborigines (Morgan 1881, reprinted 1965) and was given theoretical sophistication in Marcel Mauss and Henri Beuchat's Seasonal variations of the Eskimo: a study in social morphology, which originally appeared in the Année Sociologique (1904-5, English translation 1979). These two major studies, although developed from differing theoretical perspectives, established the initial foundation for the anthropological study of houses and their relation to social life.

Morgan's (1881) work is a continuation of his Ancient society (1877, reprinted 1964) and was originally intended to form part of that study. As such, it is a systematic work developed within a social evolutionary framework that endeavours to trace the forms of social organization associated with the stages of human progress. In Morgan's view, each of these stages from Savagery through Barbarism to Civilization was marked by a new technological development: the development of bow and arrow, the invention of pottery, the domestication of 
animals, the invention of smelting and eventually the establishment of an alphabet. The basis for virtually all forms of social organization was a lineal descent group which he termed the gens. This gens passed through successive stages of development but throughout its development was characterized by practice of hospitality and communalism (what Morgan called 'communism in living').

In retrospect, most of Morgan's comparative framework may seem a crude and cumbersome approach to an analysis of domestic architecture but for its time, it was a work of considerable sociological discernment. Morgan's bequest to anthropology has been profound. His work contributed, as a foundation work, to what seems to be an abiding obsession with descent and descent systems in anthropology. Even Morgan's evolutionary perceptions have, in various forms, continued to be of influence. It is by no means insignificant that Lévi-Strauss dedicated his first major book, The elementary structures of kinship, to Lewis H. Morgan. There would even appear to be a parallel between the way Morgan focuses on different communal house types in his developmental schema and the way Lévi-Strauss invokes the house as a type of social structure in the transition from elementary to complex structures of society.

Mauss and Beuchat's early study of domestic design is of a different order. It forms part of an extensive examination of the seasonal variations that Eskimo society undergoes in the course of a year. The change from dispersed summer dwellings to collective winter houses is taken as important evidence of social transformations which, in Mauss and Beuchat's argument, are considered within an ecological perspective. The floor plans and cross-sections of a variety of distinctive winter houses, each built with different materials, are examined to identify a common prototype. Different environmental conditions are taken into account as important factors influencing physical design. Mauss and Beuchat's argument is, however, that despite these differences, a common cultural design can be discerned and this design reflects a collective social pattern.

If Morgan was the first to examine, within an evolutionary framework, a wide range of house structures among different populations, Mauss and Beuchat were among the first to note ecological and historical factors affecting house structures among related populations with a similar culture. Subsequent research on the house, including that of Lévi-Strauss, can be situated within and among these differing perspectives.

Apart from Roxana Waterson's The living house, the most important recent work to address these issues from a predominantly Austronesian perspective is the collection of essays edited by Charles Macdonald, De la hutte au palais: sociétés "àmaison" en Asie du Sud-Est insulaire (1987). In this work Charles Macdonald considers the appropriateness of Lévi-Strauss' concept of the house in relation to the societies of the Philippines as does Bernard Sellato in relation 
to the societies of Borneo. Both researchers adopt a similar approach by ordering the societies of these areas in terms of a scale of development from simple non-stratified societies through to elaborately stratified societies. On this basis, both Macdonald and Sellato reach similar conclusions, namely that Lévi-Strauss' concept of house is of minimal analytic relevance to relatively unstratified societies and only seems relevant to those societies that are stratified and possess a quasi-feudal structure organized around a nobility. These conclusions would seem to follow from the way in which Lévi-Strauss defined his notion of the house. The result is, as Macdonald notes, that a large majority of these Austronesian societies cannot be considered 'house-societies' as designated by Lévi-Strauss (Fox 1987:172).

Sellato, for his part, recognizes 'levels' of 'house societies' in Borneo. Whereas many societies with longhouses would not meet the defining criteria for a 'house society', other societies, such as the Kenyah, whose longhouses are organized according to a chiefly and aristocratic order would indeed qualify. Two other essays in the Macdonald volume, by Antonio Guerreiro and Ghislaine Loyré, take up this notion and examine the 'house societies' of this more restricted classification. Guerreiro compares the houses of the Kayan, Kenyah and Modang while Loyré examines the houses of Mindanao, particularly the Maranao and Maguindanao.

None of the essays in the Macdonald volume are concerned to examine the organization of the house as a cultural design nor do they consider aspects of this cultural design among societies with different levels of stratification. The papers in the present volume represent societies with different levels of stratification, even in the case of those papers that deal with Borneo. Moreover they are not specifically concerned with the notion of house as posed by Lévi-Strauss. Rather they examine the house as it is internally defined and thereby suggest elements of a concept of house that are more broadly applicable among the Austronesians.

\section{Austronesian House Terms}

All the papers in this volume deal with Austronesian-speaking populations and, as a collection, they point to a range of similarities and differences in Austronesian cultural traditions associated with the house. Some of these similarities may be attributed to cultural borrowings, especially among neighbouring or near-neighbouring populations. More significant, however, are those similarities that reflect a common linguistic derivation. Comparative linguistics offers evidence of these common derivations that is of considerable value as background to the papers that comprise this volume.

Linguist Robert Blust (1976, 1980, 1987) has written extensively on the house and the principal elements of its design as they pertain to Austronesian cultural 
history. Blust (1987) has compiled a list of the principal terms that signify some kind of 'house' among the different linguistic subgroups of Austronesians and has examined these terms in detail. The lexically reconstructed forms of these various house terms are (1) * Rumaq, (2) * balay, (3) * lepaw, (4) * kamaliR, (5) * banua. (All such lexical reconstructions are conventionally designated by *.)

Although the higher order subgrouping of the Austronesian language family is still the subject of controversy, Blust's subgroup classification is widely used as a working hypothesis for current research (Pawley and Ross in press). According to this classification, the Austronesian language family divides into two major divisions: Formosan and Malayo-Polynesian. Malayo-Polynesian is in turn divided into a Western Malayo-Polynesian subgroup and an even larger and more diverse Central-Eastern Malayo-Polynesian subgroup (CEMP). This large CEMP subgroup is again divided into a Central Malayo-Polynesian and an Eastern Malayo-Polynesian subgroup. Differentiating still further, the Eastern Malayo-Polynesian subgroup is divided into a South Halmahera-West New Guinea subgroup and an Oceanic subgroup. This classification yields five higher order subgroups: (1) Formosan (F) which can in fact be further subdivided; (2) Western Malayo-Polynesian (WMP); (3) Central Malayo-Polynesian (CMP); (4) South Halmahera-West New Guinea (SHWNG) and (5) Oceanic (OC). Although the constituent status within this classification of both WMP and CMP requires further investigation, the distribution of various house terms among Blust's subgroups can be used to examine the current evidence concerning the history of the house among the Austronesians.

The first of the principal Austronesian house terms, * Rumaq, shows reflexes in all five subgroups of Austronesian. It is the most widely distributed term for 'house' and its usage among Austronesian populations is often given a metaphoric sense to define an associated social group claiming some kind of common derivation or ritual unity (Fox 1980). In terms of this volume, the Iban, Gerai and Minangkabau (whose languages are classified as Western Malayo-Polynesian) all reflect rumah, whereas the Rotinese (whose language belongs with the Central Malayo-Polynesian languages) use the cognate uma. Similar forms are widely distributed among Central Malayo-Polynesian languages: Rindi, uma; Savu, àmu; Atoni, ume; Tetun, uma; Ema, umar; Babar, em; Buru, huma; Nuaulu, numa.

Although the term * balay has no known reflexes in Formosan languages, it does take a variety of forms in both Western Malayo-Polynesian and Oceanic languages. In the Philippines, reflexes of this term (Isneg, baláy; Cebuano, baláy) may refer to a 'house' while in many Malayic languages, Minangkabau included, balai denotes a 'public meeting-house'. This is also the meaning of the Palauan bai. Other reflexes refer to a 'raised platform' or a kind of pavilion which may have a roof and walls on one or two sides, as is the case with the Balinese bale. Such structures are to be found in household compounds as well as in temples 
and other public places. In her paper, Alexander notes a seemingly similar structure that forms an adjunct to each apartment in a Lahanan longhouse. This structure called baleh, which Alexander glosses as 'kitchen' is separated from the apartment proper (tilung) by an open washing and drying platform.

In Melanesia, reflexes of * balay may refer to 'a shed for yams' or 'a garden house' (Arosi, hare) or 'a house of retirement for women during menstruation and childbirth' (Are'are, hare). In the Pacific, however, reflexes of * balay generally refer to the house proper as they do in the Philippines (Fijian, vale; Samoan, fale; Hawaiian, hale). Blust proposes an original primary gloss for this term as 'village meeting house' suggesting that the general Malayic language forms retain the original meaning, whereas those in Oceania indicate a transformation in the use of this structure.

The third term, * lepaw, has at least one identifiable reflex in a Formosan language where it refers to a 'house' (Kuvalan, lêppaw). Reflexes of this term, however, are predominantly found in Western Malayo-Polynesian languages where they have a variety of meanings. Blust (1987:91) reports three instances of this term, each with a somewhat different meaning: 'storehouse for grain' (Ngaju, lepau), 'hut, building other than longhouse' (Uma Juman, lêpo) and 'back verandah or kitchen verandah of a Malay house; booth or shop' (Malay, lepau). Alexander, in her paper, interestingly identifies the lepau among the Lahanan as a 'farmhouse' which may be either a simple shelter or a solid dwelling where families 'may spend up to a month during peaks in the swidden rice cultivation cycle'. Whittier (1978:107) reports a similar term, lepau, meaning 'field hut' among the Kenyah, and Rousseau (1978:80) the term lepo' meaning 'single family farmhouse' among the Kayan. ${ }^{1}$ Although Blust proposes an original meaning as 'granary', it would seem more appropriate to suggest a general meaning that would subsume the notion of an 'alternative dwelling', one that could be used for a variety of purposes such as hunting, gardening, marketing and even fishing.

The Samal-speaking Bajau Laut have houses (luma') raised on poles along the seashore but they also have family houseboats, known as lepa, in which they regularly spend a great deal of time fishing (Sather 1985:191-195). Such boats constitute the alternative, sea-based houses of the Bajau. As Sather explains,

a young man was outfitted with a boat at the time of his marriage. This was done so that he and his wife would be able to begin married life as an independent boat crew with their own source of income separate from the control of their parents and other kin ... [F]rom marriage onwards, nearly all men remained boat-owners for as long as they were economically active (1985:195).

Whether Bajau lepa is a reflex of * lepaw remains to be established. This usage may, however, link 'house' and 'boat' in a way that reflects earlier, more common 
Austronesian practices. Cognates of this term for boat are widely distributed among speakers of various languages of South Sulawesi (Grimes and Grimes 1987:172-173).

A fourth term for house * kalamiR, like * balay, has no recognizable reflexes among Formosan languages but has numerous reflexes in Western Malayo-Polynesian languages. In the Philippines, these reflexes generally refer to a 'granary, storehouse or barn' whereas in the Oceanic subgroup, a range of reflexes of this same term denote special 'men's houses'. Blust proposes the gloss 'men's house' for * kalamiR, having previously assigned the gloss of 'granary' to the term * lepaw. This designation assumes, however, the existence of Melanesian type men's houses among the early Austronesians prior to their contact with the non-Austronesian populations of New Guinea. The comparative Austronesian dictionary (Tryon 1993), assigns * kalamiR the gloss, 'granary, shed'. It might therefore be appropriate to see the widespread Western Malayo-Polynesian reflexes as a retention and the usages found in Oceania as an innovation.

The final house term with wide generality is * banua. Since no reflexes are to be found in Formosa, this term also has to be considered a Malayo-Polynesian construct. Reflexes occur in all subgroups of Malayo-Polynesian, but only in a scatter of languages does the term refer to the 'house' (Toraja, banua; Banggai, bonua; Wolio, banua; Molima, vanua; Wusi-Mana, wanua). Far more often reflexes of * banua denote an area that may be glossed as 'land, country, place, settlement, inhabited territory, village'. Both usages of * banua occur in different societies considered in this volume. Thus, for example, the Iban menoa rumah is the 'territorial domain' of a longhouse; manua, on Goodenough Island, refers to the 'house', but as Young (1983) notes elsewhere, manua 'also connotes "village" in the sense of dwelling place or home'. Young in fact glosses the reduplicated form of manua, manumanua, as 'staying at home' (p.55). Given the preponderant distribution of the wider meaning of * banua, there seems to be ample reason to assign the gloss of 'country, inhabited territory' to this term.

Overall the evidence of these house terms suggests that the Western Malayo-Polynesian groups retain somewhat more of the earlier traditions of the house, whereas these traditions among Central-Eastern Malayo-Polynesians have undergone transformations. As the Austronesian-speaking populations expanded, they encountered significant populations of non-Austronesian speakers in Halmahera, along the coast of New Guinea, and on many of the islands of western Melanesia. The evidence suggests that early contact and, in many areas, continuing relations between Austronesian and non-Austronesian populations was indeed of critical importance.

In addition to his examination of house terms, Blust (1976) has also endeavoured to construct the terms for some of the basic elements of the 
Malayo-Polynesian house. His linguistic evidence points to a raised structure built on 'posts' ( ${ }^{*}$ SaDiRi), entered by means of a 'notched log ladder' ( SaReZaSan), with a hearth ( ${ }^{*}$ dapuR), a 'storage rack above the hearth' ( $\left.{ }^{*} p a R a\right)$, 'rafters' ( ${ }^{*}$ kasaw), and a 'ridge-pole' ( ${ }^{*}$ bu(qS) ungbu(qS)ung) covered in 'thatch' $\left({ }^{*}\right.$ qatep). The structure defined by these elements is a familiar one through much of South-East Asia. As an architectural entity this structure is certainly not confined to the Austronesians (Izikowitz and Sorensen 1982). Henriksen (1982) reports on a neolithic house excavated at Nong Chae Sao in Thailand that could well fit this same structure. One must therefore assume that the early Austronesians and their descendants shared broadly similar South-East Asian architectural traditions and in the course of their history adapted a variety of other traditions from eastern Asia, India, the Middle East and Europe in developing their current construction techniques. Both Dumarçay (1987), succinctly in his excellent summary volume The house in South-East Asia, and Waterson (1990), at considerable length in The living house, document the remarkable mélange of architectural techniques that have influenced the construction of Austronesian houses. It is interesting to note, however, how the Austronesians transmitted elements of a South-East Asian architectural tradition to New Guinea, Melanesia and the Pacific. Brigitta Hauser-Schäublin concludes her massive two-volume study Kulthäuser in Nordneuguinea with important historical observations:

The hut on piles with supports carrying both the roof and the built-in floor seems to belong to Austronesian cultures. On the North Coast [of New Guinea] both elements are combined: the first floor platform is supported by its own poles, whereas the upper floors are slotted into the horizontal beams. In areas settled by non-Austronesian groups, all parts of the building are traditionally lashed with lianas. The Middle Sepik cultures are masterpieces of this highly developed binding technique. Pin and peg techniques are only known in those regions where Austronesian languages are spoken. The Middle Sepik cultures took over the idea of buildings with projecting gables from the Austronesians who settled at certain places on the North Coast. They adapted it to their own technology and architectural experience, giving it a new expression (Hauser-Schäublin 1989:618).

Perhaps the most significant aspect of the terms for the house that can be reconstructed for Proto-Malayo-Polynesian is their saliency for defining prominent features of the house among the Austronesians. Posts and ladder, ridge-pole and hearth within an encompassing roof are the elements of the house most frequently marked as the foci of rituals for the house. They are the principal ritual attractors in the house. The papers in this volume direct attention to this important aspect of Austronesian houses. 


\section{Ordered Structures and Their Orientation}

One common feature of traditional Austronesian houses is their ordered structure. For many houses, this structure consists of a formal orientation. The spatial coordinates of this orientation vary considerably from one Austronesian society to the next. Such coordinates may be either external or internal to the house itself or, in fact, both. Where they are external, they represent a wider orienting framework - often a cosmological orientation — within which the house must be positioned. Where, however, links to a wider cosmological orientation have been severed or are no longer considered relevant, houses may still be ordered in terms of a set of internal orienting principles. The pattern of building may follow a fixed order and certain features of the houses - certain beams, posts, corners - may constitute points of reference. These points of reference act as ritual attractors around which critical activities are organized.

The house may be complete unto itself in creating its internal structure without reference to external coordinates. In some instances, however, the application of similar coordinates, differentially applied, may distinguish the internal orientation of the house from the external system (see Fox, Comparative Postscript on Houses on Roti and on Timor, pp.170-177 this volume). Yet, however it is constituted, this ordered structure is critical to the activities, particularly the ceremonial activities, conducted within the house. A variety of the ways in which Austronesian houses constitute ordered structures are illustrated in this volume.

The Lahanan longhouse, for example, follows a common Borneo pattern, one that sets the house in a wider orientation. The Lahanan longhouse is always built parallel to a river with its veranda or gallery facing the river. The longhouse is thus oriented in terms of the coordinates of 'upriver' (naju) and 'downriver' (nava). In relation to the river, one 'goes up' (baguai) to the house and 'down to work' (ba'ai nyadui) toward the river. In the settlement described by Alexander, the longhouse was built along a main river or 'trunk' (batang) and the headman's apartment, whose gallery is 'the locus of religious and social activity', was located on the 'downriver' end of the house.

The Iban longhouse has a similar orientation which Sather, in his paper, presents as fundamental:

As riparian settlements, Iban longhouses are built along rivers and streams with their long axis ideally oriented parallel to the main river course. Consequently, the two ends of a longhouse are normally distinguished as the 'upriver' (ulu) and 'downriver' (ili) ends ... This orientation, as well as the presence of a centralizing 'source', is basic and is evoked constantly in everyday speech.

To this is added another set of coordinates, as Sather also notes: 
A second basic orientation of the longhouse is in terms of the sun's movement through the sky, from east to west ... The gallery side of the house should thus ideally face eastward, in the direction of the rising sun.

A further set of coordinates involves a relationship between 'base' and 'tip'. Both the main river and the longhouse are described as a 'trunk' (batang) and this trunk is conceived of with its 'base' (pun) as 'downriver'. Thus the apartment of the ritual custodian of the longhouse (pun rumah), like that of the Lahanan headman, is positioned 'downriver' from the central post (tiang pemun) of the house.

The Rotinese house, like many traditional houses in eastern Indonesia, is based upon a set of external spatial coordinates. For the Rotinese, these coordinates are the directional coordinates of the island and are considered to represent a basic cosmological order. Houses are supposed to have their 'head' (langa) to the east (dulu) and their 'tail' ( $i k o$ ) to the west. This axis is recognized as the path of the sun. Entrances to the house may be either from north or south, directions which are synonymous in Rotinese with 'left' (ki) and 'right' (kona). (The further coordinates of 'up' or 'skyward' (lai) and 'down' or 'earthward' (dae) differentiate levels within the house.) The internal spatial layout of the house is based on the directional coordinates but is specially marked in terms of a single post known as the 'right post' (di kona) whose invariant position is in the south-eastern corner of the house. This entire structure is conceived of as a creature with its head to the east and its tail to the west; the rafters of the house are its ribs and the ridge-pole its spine.

Van Meijl describes virtually the same kind of structure for the Maori meeting-house: 'Meeting-houses are not only named after an ancestor. Their structure represents the body of an eponymous ancestor too'. The ridge-pole is the spine, the rafters are the ribs, the bargeboards the arms, the front window the eye, and the juncture of the eaves of the veranda represents the face. The interior of the house is the chest. Unlike the Rotinese house, however, this ancestral body is not reported to be oriented in any particular direction, yet internally, within this body, van Meijl describes various areas on the right and left sides of the house and in the front and rear that are complementary to one another and considered to be relatively 'sacred' (tapu) or 'common' (noa).

The definition of 'inside' is a relative notion within traditional Austronesian houses. Although 'inside' may include everything beneath the roof, more often the category of 'inside' (Proto-Austronesian, * Dalem) is specifically defined. In the Rotinese house, the 'inner house' (uma dalek) refers to the 'female' precinct on the western side of the house. In the Gerai house, lem uma is the inside of the apartment' defined by the door (lawang) as opposed to the gallery (ruang) which is described as 'outside' (sawah). Helliwell's description of the Gerai house 
concentrates on this orientation within the house and its implications in distinguishing between 'we' and 'other'. By contrast, the rumah dalam in the Minangkabau house is an enclosed space under the house set aside for women to weave in. From Ng's description, it would appear that, unlike other sections of the house, this space is not open for use on ceremonial occasions.

All of these differently defined sections of the house have 'female' associations as, indeed, does the house as a whole in many contexts. The Javanese term dalem epitomizes these various senses. Dalem is 'house' (omah) in the highest Javanese speech register; in a lower register, however, it may refer to the inner family room(s) of an ordinary house or to the inner precinct of a palace, which is not considered to be the place of the ruler but rather the most private abode of the women of the palace. Some Javanese see this dalem as the sacred resort of a female goddess (see Mangunwijaya 1991:13).

Of all the houses described in this volume, the Kalauna house appears at first to be anomalous. Young remarks that the 'Kalauna house has no particular orientation, no symbolically salient "sides" or halves, no interior demarcations'. Yet all Kalauna houses are aligned to face particular atuaha platforms associated with specific descent groups. As places for work and gossip as well as being sites for ritual, these platforms must be considered as an essential extension of the house itself. Although houses have 'mouths' (awana) as doorways and 'eyes' (matana) as windows, such symbolism is not, as Young points out, systematically developed. The house is predominately defined as 'inside'. Thus Young notes that 'the house's interior (vetawana) is symbolically salient itself: as concealed interiority, a domain of nafone, "inside" or "within-ness" '. The house is both a repository for ancestral relics and magic paraphernalia and an abode for the spirits of the ancestral dead. Key components of the house - the ridge-pole and even the walls - are believed to be occupied by these spirits of the dead. In this sense, the Kalauna house is considered to be 'animated' as an ancestral embodiment.

\section{Structures of Origin Within Austronesian Houses}

Among the Austronesians, a concern with 'origins' is of paramount social importance. This concern with 'origins' is more than a concern with 'descent'. Indeed, in many Austronesian societies, the concern with 'descent' (as it has been generally defined) is of minor significance. By contrast, the concern with 'origins' constitutes a fundamental epistemological orientation and takes on a remarkable variety of forms (Fox 1971, 1980a:14, 1988:14-15, n.d.a). This concern is manifest in complex origin narratives - elaborate accounts of the emergence and/or the arrival of predecessors; traditions of the migration and journeying of groups and individuals; tales of the founding of settlements, of houses, or of ancestral shrines; accounts of contests to establish priority, to secure the rightful transmission of ancestral relics, to assert the often disputed ordering of succession 
to office or, in some areas, to establish precedence in affinal relations. This concern with 'origins' is essential for social identity and social differentiation.

It is particularly interesting to note the way in which the idea of 'origin' is commonly designated in a large number of Austronesian languages. One such category for designating 'origin' refers to the 'base' or 'trunk' of a tree thus connoting and conflating ideas of 'base', 'trunk', 'cause', 'beginning', 'source' and 'origin'. The idea of origin is thus conceived of, in a botanic idiom, as a kind of epistemic development from a 'base' to a 'tip' or, more divergently, to a myriad of separate 'tips' (Fox 1971).

Houses, by the nature of their construction, lend themselves to the expression of this botanic metaphor of origin. Waterson in her paper explicitly notes this use: "botanic metaphors of "trunk" and "tip" occur not only in rules about the correct "planting" of house posts but as ways of talking about kinship' (see also Waterson 1990:124-129). Houses may thus express critical relationships among groups based on locally defined concepts of origin and derivation.

In terms of these conceptions of origin, Lévi-Strauss' comments on the layout of the traditional Karo Batak house, as described by Masri Singarimbun (1975) in his monograph Kinship, descent and alliance among the Karo Batak, take on special significance. Lévi-Strauss (1987) notes two critical features of Karo society: that wife-givers are superior to wife-takers and that the foundation of a village requires the participation of wife-givers with subordinate wife-takers. Traditional houses, consisting of as many as eight resident families living juxtaposed to one another, also reflect these fundamental relationships. Thus, as Lévi-Strauss indicates,

the family of the dominant lineage occupies the so-called 'base' apartment and its wife-taking family occupies the so-called 'summit' apartment, inferior as such (because the base is larger and stronger), but favoured because it is situated on the eastern side, from whence comes the fresh morning breeze, which is more agreeable to the inhabitants than the oppressive heat of the afternoon, which has a negative connotation, and which the dominant family faces in order to protect the other apartments (1987:157).

Although Lévi-Strauss sees in this situation a contradiction between the Karo system of marriage alliances and its political and residential rules, his description closely follows Singarimbun, who sees no evident difficulties in these household arrangements:

The social organization of the house is related to this organization of its internal space because the apartment called 'the base of the tree' is the place of the chief of the house (pengulu rumah), and opposite to him, occupying the apartment called 'the top of the tree', is his deputy who 
is one of his jurally inferior anakberu [wife-takers] ...the Karo house has an east-west orientation and the apartment of the head of the house is located at the west end, facing the heat of the afternoon sun, because he is regarded as one who is able to confront 'heat' or in other words, 'evil' (Singarimbun 1975:61-62).

Singarimbun's examination of the Karo house is in fact more complex than is indicated by Lévi-Strauss in that it distinguishes a set of shared household arrangements based on a contrast not just between 'base of the tree' (benakayu) and 'top of tree' (ujungkayu) but also those households 'opposite' (lépar) the 'base' and 'top'. Critical to all of these relationships within the house is the sharing of kitchen cooking fires. Households divide according to whether they 'share a kitchen' with the 'base' or 'top' or with households opposite to the 'base' or 'top'. Although related as wife-giver to wife-taker or as 'chief' and 'deputy', the families of the 'base' and 'top' are set furthest from one another in their cooking arrangements.

Although his purpose was to draw conclusions about the nature of affinal relations, Lévi-Strauss does highlight a feature of the traditional Karo house that is common to a wide variety of Austronesian houses and is well exemplified, for example, in this volume by the Minangkabau and Borneo cases.

Cecilia $\mathrm{Ng}$ notes the use of a similar metaphor to distinguish social and ritual positions in the Minangkabau house. The traditional Minangkabau house is built as a women's domain where men, as husbands, are received as 'guests'. Within this structure, the pangkalan (from pangkal meaning 'base', 'beginning', 'origin') defines a specific area on one end of the house. The pangkalan is the section of the house that adjoins the kitchen and the area through which all guests enter the ruang. Between these two areas is the central post of the house. Set lower than the elevated anjuang at the opposite end of the house, the pangkalan is opposed to the anjuang. In her analysis of women's life cycles within the house, $\mathrm{Ng}$ points to the fact that women move from sleeping near the central post into the anjuang when they marry and then through separate apartments until they end their reproductive life and come to sleep in the pangkalan on the opposite side of the central post. Here 'base' and 'pinnacle' describe not a set of affinal relationships, as in the case of the Karo Batak house, but rather a sequence of reproduction and its celebration within the matrilineal Minangkabau group.

Clifford Sather also devotes a considerable portion of his paper to the careful examination of the categories of 'base' and 'tip', of the use of these categories in defining spatial arrangements within the Iban house and of their fundamental association with ideas of origin and continuity. His analysis, like that of $\mathrm{Ng}^{\prime}$, is too extensive and detailed to be simply summarized. Its comparative significance, however, is worth noting. The Iban term for 'base', 'source' or 'origin' is pun, which derives from the Proto-Austronesian term * puqun meaning 
'tree', 'trunk', 'base' or 'source'. With the insertion of an infix, pun gives rise to pemun, which is the term applied to the 'source post' (tiang pemun) of the Iban longhouse. The central source post is the first post of the house to be erected; then the building of the house proceeds, first downriver, then upriver, with each apartment given its own tiang pemun that is ritually subordinate to the central source post. The term pun is applied not just to the posts of the house but refers equally to persons and directions. When applied to persons, pun also has the sense of 'initiator' or 'founder' but implies a continuity with the past generations. Each longhouse has one pun rumah who is the custodian of the central tiang pemun of the house and is required to maintain the ritual welfare of the house as a whole. Each apartment has its own pun bilik who is the caretaker of the family's tiang pemun and of its ancestral sacra, which include its ritual whetstones and special 'source rice' (padi pun). In all of these usages, the metaphor of 'base' and 'tip' defines a direction of life and growth as indeed it defines precedence among groups within the longhouse.

The Lahanan, like the Iban, rely on the notion of 'base' as origin and use this concept to distinguish groups within the longhouse. Most apartments (tilung) in a Lahanan longhouse consist of single households, generally organized as stem families. Those who reside in an apartment are known as the "people of the apartment' (linau tilung). However, as Jennifer Alexander makes clear, the ownership of the apartment and its contents, its heirlooms and all rights to land are not vested in this circumscribed residential group but rather in what is called the tilung pu'un or tilung asen - the 'tilung of origin'. Alexander describes the tilung pu'un as 'a kinship group comprising all persons with consanguineal links to the tilung, irrespective of where they may be living'. Heirlooms provide the symbolic focus for this tilung pu'un. Rights to these heirlooms and to land belong to all members of the group; the custodial role is given to the senior member of the residence group. Since, as Alexander goes on to point out, 90 per cent of married couples live in the wife's apartment, female lines provide the continuity of this group and most custodians of property are women. ${ }^{2}$

Houses in eastern Indonesia are often explicitly designated according to 'origin', using the same metaphor of 'base' as in Borneo or Sumatra. The continuity implied by these origins, which in some societies is defined lineally and in others affinally, may be traced through houses but is not defined exclusively by them. On Timor, such designations are applied among affinally related groups that are identified as 'houses'. Thus among the Ema, 'houses' that bestow women on other 'houses' are known as the uma mane pun, 'the base houses of the wife-givers' (Clamagirand 1980:142); among the Mambai, houses in similar relationships are designated as umaen fun, 'wife-givers of origin' (Traube 1980:353 n.10). Such houses are regarded as established life-giving progenitors. 
Among the Rotinese such progenitor designations are not applied to houses but to persons. Instead of uma mane pun or umaen fun, the Rotinese identify lines of former wife-givers as to'o-huk, 'mother's brother of origin', and the bai-huk, 'mother's mother's brother of origin' (pun, fun and huk all deriving from Proto-Austronesian * puqun). Rotinese houses, however, figure prominently in the ritual display of these relationships. On either side of the ladder, heda-huk (which was formerly a notched tree trunk), leading up into the house itself are two specially named positions: the sosoi dulu and the sosoi muli. These are the recognized ritual positions for the 'mother's brother of origin' and the 'mother's mother's brother of origin'. At mortuary rituals, only the progenitors in the maternal line of origin have the right to sit at these places and to be fed before all other guests. These positions are at the entrance to the house and are not associated with the ritually most important post in the house, the 'right post' (di kona) which is located in the south-eastern quadrant of the house.

Maori define 'origins' using a combination of terms for 'growth' (tupu), for 'ancestor' (tupuna or tipuna) and for 'base', 'origin', 'cause', 'source' (puu) (Salmond 1991:344-345). The term hapuu (from puu), often translated as 'sub-tribe' or clan, can in fact refer to groups of varying size who trace their origin from a particular ancestor (tupuna). Maori meeting-houses (whare hui) are also considered to be 'ancestral houses' (whare tupuna) and as such, they are the focal point for particular local groups (taangata whenua: whenua $>{ }^{*}$ banua). As van Meijl explains in this volume,

[i]n meeting-houses owner groups, usually subtribes, symbolize their unity and their distinction from other subtribes ... Meeting-houses are not only named after an ancestor. Their structure represents the body of the eponymous ancestor too ... The ridge-pole (taahuhu) is regarded as his spine representing the main line of descent from the apex of the (sub)tribe's genealogy. The rafters (heke) are his ribs representing junior descent lines derived from the senior line or taahuhu.

These ancestral representations as well as those carved on the 'face' of the house, combined with the 'old portraits of ancestors' and 'photographs of recent forbears' that hang on the walls make the Maori meeting-house a pre-eminent structure for the display of origins.

\section{Time and Memory in Austronesian Houses}

In recounting the oral histories of the Ilongot, a small population of shifting cultivators in northern Luzon, Renato Rosaldo (1980) explains that the Ilongot 'readily listed in succession the names of the places where they had "erected their houseposts" and "cleared the forest"" (p.42). ${ }^{3}$ Remembering the bamboo, once planted near a house, serves as another icon of the previous occupation of a site. 
Using lists of place names, crude sketches and more detailed contour maps, Rosaldo was able to reconstruct a remembered past among the Ilongot - a past that was structured on a chronology of changing household residence: 'to coordinate one household history with others was vexing because clusters of houses split, then joined and split, then joined again' (Rosaldo 1980:42). In all of these bewildering shifts, one constant is the rule of residence that a man reside with his wife. Although the man is described as the 'source' (rapu) of courtship, he 'goes into' the house of the woman (p.179). A further rule that the youngest married daughter reside with and care for her aged parents provides the basis for continuity across generations.

Among the Ilongot, houses are shifted every four or five years and it is noteworthy that in tracing these shifts, the Ilongot allude to their houses, not as entire structures, but in terms of the memory of the erection of houseposts. This focus on the posts of the house is a significant feature of many Austronesian houses. The papers in this volume make clear the ritual significance associated with the 'central post' (tonggak tuo) in the Minangkabau house, the 'source posts' (tiang pemun) in the Iban longhouse, and the 'right post' (di kona) in the Rotinese house. All of these posts are ritual attractors within the house. Not only are these posts given special prominence in the ceremonies associated with the building process, they are also preserved, if possible, when an older house is dismantled, and used to form a (ritual) part of the new structure. The authors of the beautifully illustrated volume Banua Toraja: changing patterns in architecture and symbolism among the Sa'dan Toraja, Sulawesi-Indonesia emphasize this point in their discussion of the 'navel post' (a'riri posi') of the Torajan house:

During the rebuilding of a tongkonan, the erection of the new a'risi posi', or of the original pillar saved from the old house, takes place during the three great feastdays of the house's consecration ... The pillar is decorated with a sacred $m a a^{\prime}$ cloth, the young, yellow leaves of the sugar palm, and the red leaves of the Cordyline terminalis (Kis-Jovak et al. 1988: 40).

The housepost expresses an idea of botanic continuity that is consistent with the overall imagery of the house. Sather, for example, notes in this volume that 'the ordering of the tiang pemuns creates the image of the longhouse as an upright tree'. The same observation can be made of the Torajan house. Waterson observes that

those who trace their descent from a common pair of founding ancestors, man and woman, are called pa'rapuan or rapu. Rapu tallang in Torajan means 'a stool of bamboo'. The family is compared to the bamboo whose many stems sprout from a single clump. The tongkonan, especially when being referred to in the most general sense of an origin-house, regardless of rank, is often called the banua 1 pa'rapuan or 'house of the pa'rapuan'. 
From the same root is derived an adjective, marapuan, which means 'having a great many descendants' (1986:97).

The authors of Banua Toraja make this image of the tree explict: 'The house itself, the centre for the rapu, is often compared to a tree' (Kis-Jovak et al. 1988:39).

A tree with many branches emanating from a single base or a stand of bamboo with multiple stems sprouting from one clump are two among many botanic icons that, among Austronesians, translate spatial imagery into a temporal sequence. The 'base' is prior and takes precedence.

A set of categories that effects a similar translation consists of the opposed terms for 'front' and 'rear' which may equally be applied to 'that which comes before' and 'that which comes after' in a temporal as well as a physical sense. In his paper, van Meijl considers the use of these categories in the Maori meeting. In Maori, the past is referred to in terms of mua, 'that which has gone before', ngaa raa o mua, 'the days in front', in constrast with what follows after, kei muri. Following Salmond (1978), van Meijl notes that

the place of the seniors (past) in the front and the more junior (future) towards the rear of the house, corresponds with the temporal succession from the remote past to the more recent past, toward the future.

A similar set of categories are applied to the Rotinese house. These categories are dulu/muli. Dulu is the term for 'east', the 'direction of the rising sun'; muli for 'west', the direction of the setting sun. Since the house is oriented on an east-west axis, the 'outer' section of the house is to the east and the 'inner' section to the west. This context creates a series of associations that contrast the first-born (uluk) who is elder and foremost but who must go 'out' from the house with the last-born (mulik) who is junior but who will stay 'in' the house and inherit it. The categories combine to interrelate temporal and spatial orders. Essentially, however, they establish different relationships of precedence. These different relationships are not, however, coincident nor are they simple reflections of one another. Thus in assigning ritual positions to the 'mother's brother of origin' and 'mother's mother's brother of origin', it is the (later) progenitor relationship of the mother's brother that is given precedence at the eastern position (sosoi dulu) in the house. As is discussed in this volume, in the case of the Minangkabau house and of the Iban house, this categorization of the Rotinese house creates a ritual arena within which the temporal sequence of ceremonies from birth to death can be carefully conducted.

From Roman times to the Renaissance, Western scholars cultivated, as a formal technique of the art of rhetoric, a tradition that assigned to particular locations within an imagined house a sequence of ideas or objects that were to be memorized. The house, in this tradition, was made to serve as a structure for 
remembering. One of the arguments in the paper on the Rotinese house is that this association of ideas with locations within the house is an implicit feature of many Austronesian cultures. It is in the rituals of the house that these ideas are recollected and enacted, thus making the house not just a 'memory palace' but a 'theatre of memories'.

\section{Concluding Remarks}

It is probably wise to conclude this introduction on a cautionary note. In a recent paper, Roy Ellen (1986) has provided a remarkable examination of the Nuaulu house on the island of Seram in eastern Indonesia. His description of the Nuaulu house is exemplary in its detail. Houses (numa) are occupied by extended family groups or households (also termed numa) which form the minimal corporate units of Nuaulu society. Houses are built on posts (hini) that are always ritually 'planted' in their 'natural orientation' with their 'roots' in the ground. Such properly planted houses are generally referred to as 'sacred houses' (numa mone) and are the depositories for ancestral objects. Most of them are clan section houses and are associated with elaborate ritual activities. These houses are also ordered structures. They are oriented according to intersecting coordinate axes (mountain/sea :: north/south; sunrise/sunset :: east/west) and these axes are given gender associations as male and female. The north-east corner of the house (identified as male and defined by the intersection of mountain/sunrise) is considered as the 'most sacredly charged' point in the house. Ellen describes the inner layout of the house and relates this structure to the layout of the village and central position of the village ritual house (suane). Having systematically constructed this complex analysis of the house in Nuaulu social life, Ellen argues against the tendency to conflate different levels, categories and metaphoric expressions in a total symbolic conflation: 'To compress all symbolic domains together in a totality is artificial and certainly does not reflect "local models", or symbolic consciousness' (p.23). This is a view shared by all the contributors to this volume and is most clearly and emphatically articulated by Clifford Sather who argues that the Iban longhouse represents 'a plurality of symbolic orders' - orders that are not only multiple but also constantly 'created and re-created in ritual'.

By necessity, each of the papers in this volume can only provide a glimpse inside a particular Austronesian house. The intention is not, however, just to point to the complexity of these structures as designs for living and the plurality of the symbolic orders that are created within them, but to indicate an important comparative dimension to this complexity and plurality. One only has to read these papers to get a sense of the family resemblances that exist among Austronesian houses, not just in physical structures but, more importantly, in the fundamental categories by which these structures are culturally ordered. It is hoped therefore that this volume will prompt the further comparative study 
of Austronesian houses while it is still possible to do so and before these remarkable dwellings give way to new residential units.

\section{References}

Bellwood, Peter, James J. Fox and Darrell Tryon

n.d. The Austronesians in history (forthcoming).

Blust, Robert

1976 Austronesian culture history: some linguistic inferences and their relations to the archaeological record. World Archaeology 8(1):19-43. Reprinted in P. van de Velde (ed.) Prehistoric Indonesia: a reader (Verhandelingen van het Koninklijk Instituut voor Taal-, Land- en Volkenkunde 104), pp.218-241. Dordrecht: Foris Publications (1984).

1980 Early Austronesian social organization: the evidence of language. Current Anthropology 21:205-247.

1987 Lexical reconstruction and semantic reconstruction: the case of Austronesian 'house' words. In Diachronica IV(1/2):79-106.

Clamagirand, Brigitte

1980 The social organization of the Ema of Timor. In J.J. Fox (ed.) The flow of life: essays on eastern Indonesia, pp.134-151. Cambridge: Harvard University Press.

Dumarçay, Jacques

1987 The house in South-East Asia (M. Smithies trans. and ed.). Singapore: Oxford University Press.

Ellen, Roy

1986 Microcosm, macrocosm and the Nuaulu house: concerning the reductionist fallacy as applied to metaphorical levels. Bijdragen tot de Taal-, Landen Volkenkunde 142(1):1-30.

Fox, James J.

1971 Sister's child as plant: metaphors in an idiom of consanguinity. In R. Needham (ed.) Rethinking kinship and marriage, pp.219-252. London: Tavistock.

1980a Introduction. In J.J. Fox (ed.) The flow of life: essays on eastern Indonesia, pp.1-18. Cambridge: Harvard University Press.

1980 b Comment on Blust: 'Early Austronesian social organization'. Current Anthropology 21:233-235.

1987 The house as a type of social organization on the island of Roti, Indonesia. In C. Macdonald and members of l'ECASE (eds) De la hutte au palais: 
sociétés "àmaison" en Asie du Sud-Est insulaire, pp.215-224. Paris: CNRS Press.

1988 Origin, descent and precedence in the study of Austronesian societies. Public lecture, in connection with De Wisselleerstoel Indonesische Studien, 17 March 1988, Leiden University.

n.d.a Origin structures and systems of precedence in the comparative study of Austronesian societies. Forthcoming in P.J.K. Li (ed.) Proceedings of the international symposium on Austronesian studies relating to Taiwan. Taipei: Academia Sinica.

n.d.b Genealogy and topogeny: toward an ethnography of Rotinese ritual place names. Forthcoming in J.J. Fox (ed.) The poetic power of place. Canberra: Department of Anthropology, Research School of Pacific Studies, The Australian National University.

Grimes, Charles E. and Barbara D. Grimes

1987 Languages of South Sulawesi (Materials in Languages of Indonesia No. 38; Pacific Linguistic Series D No. 78). Canberra: Department of Linguistics, Research School of Pacific Studies, The Australian National University.

Guerreiro, Antonio

1987 "Longue maison" et "grande maison", considérations sur l'ordre social dans le centre de Bornéo. In C. Macdonald and members of l'ECASE (eds) De la hutte au palais: sociétés "àmaison" en Asie du Sud-Est insulaire, pp.45-66. Paris: CNRS Press.

Hauser-Schäublin, Brigitta

1989 Kulthäuser in Nordneuguinea, 2 vols (Abhandlungen und Berichte des Staatlichen Museums für Völkerkunde Dresden No. 43). Berlin:

Akademie-Verlag.

Henriksen, Merete Aagaard

1982 The first excavated prehistoric house site in Southeast Asia. In K.G. Izikowitz and P. Sorensen (eds) The house in East and Southeast Asia: anthropological and architectural aspects (Scandinavian Institute of Asian Studies Monograph Series No. 30), pp.17-24. London: Curzon Press.

Hudson, A.B. and Judith M. Hudson

1978 The Ma'anyan of Paju Empat. In V.T. King (ed.) Essays on Borneo societies (Hull Monograph on Southeast Asia No. 7), pp.215-232. Oxford: Oxford University Press.

Izikowitz, Karl G. and P. Sorensen (eds) 
1982 The house in East and Southeast Asia: anthropological and architectural aspects (Scandinavian Institute of Asian Studies Monograph Series No. 30). London: Curzon Press.

Kis-Jovak, Jowe Imre, Hetty Nooy-Palm, Reimer Schefold and Ursula SchulzDornburg

1988 Banua Toraja: changing patterns in architecture and symbolism among the Sa'dan Toraja, Sulawesi-Indonesia. Amsterdam: Royal Tropical Institute.

Lévi-Strauss, Claude

1969 The elementary structures of kinship (translated by J.H. Bell, J.R. von Sturmer and R. Needham (ed.)). Boston: Beacon Press. (Orig. pub. as Les structures élémentaires de la parenté. Paris: Presses Universitaires de France, 1949.)

1987 Anthropology and myth: lectures 1951-1982. Oxford: Basil Blackwell. (Orig. pub. as Paroles données. Paris: Libraire Plon, 1984.)

Loyré, Ghislaine

1987 Les maison de Mindanao. In C. Macdonald and members of l'ECASE (eds) De la hutte au palais: sociétés "àmaison" en Asie du Sud-Est insulaire, pp.89-107. Paris: CNRS Press.

Macdonald, Charles

1987 Sociétés "àmaison" et types d'organization sociale aux Philippines. In C. Macdonald and members of l'ECASE (eds) De la hutte au palais: sociétés "àmaison" en Asie du Sud-Est insulaire, pp.67-87. Paris: CNRS Press.

Mangunwijaya, Y.B.

1991 The weaverbirds (translated by Thomas M. Hunter). Jakarta: The Lontar Foundation. (Orig. pub. as Burung-burung manyar. Jakarta: Penerbit Djambatan, 1981.)

Mauss, Marcel with H. Beuchat

1979 Seasonal variations of the Eskimo: a study in social morphology (translated with a foreword by James J. Fox). London: Routledge and Kegan Paul. (Orig. pub. as 'Essai sur les variations saisonnières des sociétés Eskimos: étude de morphologie sociale' in Année Sociologique 1904-5, 9:39-132.)

Morgan, Lewis H.

1964 Ancient society; or researches in the lines of human progress from savagery through barbarism to civilization (L.A. White (ed.)). Cambridge: Harvard University Press. (Orig. pub. 1877.) 
1965 Houses and house-life of the American aborigines. Chicago: University of Chicago Press. (Orig. pub. in Contributions to North American Ethnology, Vol. 4. Washington: Government Printing Office, 1881.)

Morris, H.S.

1978 The Coastal Melanau. In V.T. King (ed.) Essays on Borneo societies (Hull Monograph on Southeast Asia No. 7), pp.37-58. Oxford: Oxford University Press.

Pawley, Andrew and Malcolm Ross

In press Austronesian historical linguistics and culture history. Annual Review of Anthropology 22.

Rosaldo, Renato

1980 Ilongot headhunting 1883-1974: a study in society and history. Stanford: Stanford University Press.

Rousseau, Jérôme

1978 The Kayan. In V.T. King (ed.) Essays on Borneo societies (Hull Monographs on Southeast Asia No. 7), pp. 78-91. Oxford: Oxford University Press.

Salmond, Anne

1978 Te Ao Tawhito: a semantic approach to the traditional Maori cosmos. The Journal of the Polynesian Society 17:5-28.

1991 Tipuna-ancestors: aspects of Maori cognatic descent. In A. Pawley (ed.) Man and a half: essays in Pacific anthropology and ethnobiology in honour of Ralph Bulmer, pp.343-356. Auckland: The Polynesian Society.

Sather, Clifford

1985 Boat crews and fishing fleets: the social organization of maritime labour among the Bajau Laut of southeastern Sabah. Contributions to Southeast Asian Ethnography No. 4:165-214.

Sellato, Bernard

1987 Note préliminaire sur les sociétés “àmaison” àBornéo. In C. Macdonald and members of l'ECASE (eds) De la hutte au palais: sociétés "àmaison" en Asie du Sud-Est insulaire, pp.15-44. Paris: CNRS Press.

Singarimbun, Masri

1975 Kinship, descent and alliance among the Karo Batak. Berkeley: University of California Press.

Traube, Elizabeth

1980 Mambai rituals of black and white. In J.J. Fox (ed.) The flow of life, pp.290-314. Cambridge: Harvard University Press. 
Tryon, Darrell T.

1993 The comparative Austronesian dictionary. Berlin: Mouton de Gruyter.

Waterson, Roxana

1986 The ideology and terminology of kinship among the Sa'dan Toraja. Bijdragen tot de Taal-, Land-en Volkenkunde 142:87-112.

1990 The living house: an anthropology of architecture in South-East Asia. Singapore: Oxford University Press.

Whittier, Herbert L.

1978 The Kenyah. In V.T. King (ed.) Essays on Borneo societies (Hull Monographs on Southeast Asia No. 7), pp.92-122. Oxford: Oxford University Press.

Young, Michael W.

1971 Fighting with food: leadership, values and social control in a Massim society. Cambridge: Cambridge University Press.

1983 Magicians of Manumanua: living myth in Kalauna. Berkeley: University of California Press.

\section{Notes}

I would like to thank all of those individuals who offered comment and suggestions in the preparation of this introductory essay. In the first instance, thanks are due to the contributors to this volume, since this paper is written as a result of the careful reading of their contributions. In particular, I would also like to thank Penelope Graham, Charles Grimes, Clifford Sather and S. Supomo.

1 Care and caution is necessary in attempting to trace the various reflexes of * lepaw. Whittier (1978), for example, notes that the Kenyah term for 'village' is lepo. This term is not to be confused with the Kenyah term lepau, meaning 'field hut'. Some Kenyah populations, such as the Lepo Tau, Lepo Tukang and Lepo Jamuk, use lepo as an identification of their specific origins. Cognates of lepo meaning 'village' would seem to be widespread. Thus, for example, among the Lamaholot-speaking populations from east Flores to Alor, lewo designates 'village', marked by a communal ritual house, which functions as a meeting-house of the clans as well as a temple of the ancestral religion (P. Graham, personal communication). From this perspective, it would appear that the Ma' anyan term lewu' for 'village house' (Hudson and Hudson 1978:215), and the Melanau term lebu for 'village longhouse' (Morris 1978:41) are cognates of the Kenyah term lepo rather than of lepau. Alexander, in her paper, provides further strong evidence for this distinction. The Lahanan clearly distinguish between the two terms levu, meaning 'longhouse', and lepau, meaning 'farmhouse'.

2 In terms of a comparative sociology of Borneo societies, the tilung pu'un of the Lahanan is structurally (as well as metaphorically) similar to the lamin po'on, the 'natal household' group described by Whittier (1978:104-106) for the Kenyah, although among the Kenyah there appears to be a lesser tendency toward female lines of continuity.

${ }^{3}$ This kind of ordered succession of places names, which is similar in structure to an ordered succession of ancestral names, is a common feature in many Austronesian societies. Such an ordered succession of place names, analagous to a genealogy, is what I have labeled a 'topogeny' in a paper entitled 'Genealogy and topogeny: toward an ethnography of Rotinese ritual place names' in a forthcoming collection of comparative essays on ideas of 'place' in Austronesian societies - The poetic power of place (Fox n.d.b). 

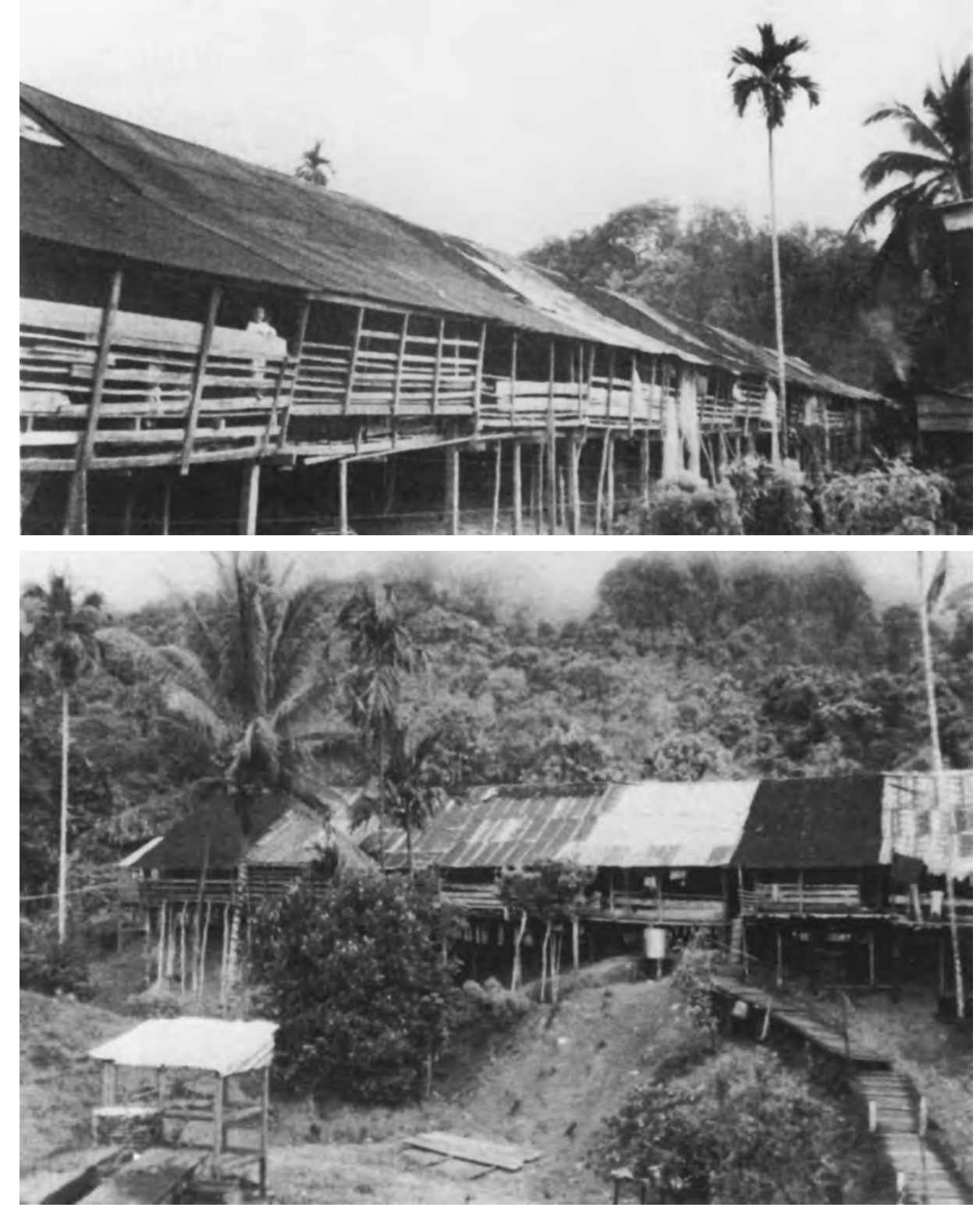

Views of a Lahanan longhouse and its communal veranda 